\title{
Aging Effect on Nectar Production in Two Clones of Asclepias syriaca
}

\author{
A.K. Southwick and E.E. Southwick \\ University of Michigan, Biological Station, Pellston, MI 49769, USA
}

\begin{abstract}
Summary. In common milkweed (Asclepias syriaca), flower nectar volumes, concentration and sugar production varied according to the age of the sampled blossoms. In individual blossoms, nectar production peaked daily at $0800 \mathrm{hr}$. Peak production during the life of the flower occurred on the second day of flowering, $50 \mathrm{~h}$ after anthesis, and nectar production ceased after $120 \mathrm{~h}$. The amount and quality of nectar were affected by microclimatic conditions and varied between clones. However, the same secretory patterns were found in all flowers studied. This age dependent nectar secretion combined with the sequential mode of flowering found on a single stem, results in substantial reward for extended periods to nectar feeders.
\end{abstract}

\section{Introduction}

Nectar production plays a vital role in the pollination of flowering plants. Much work has been done on nectar production and pollinator interaction, especially in tropical, southern and southwestern American species, and north European species. However, relatively few data are available for plants in northern habitats in the United States (Baker and Baker 1975, 1979; Beutler 1953; Beutler and Schöntag 1940; Corbet et al. 1979; Huber 1956; Loper, Waller and Berdel 1976; Robinson and Oertel 1975; Southwick et al. 1981; Wykes 1953). Much of the previous work on flower nectar has not taken into account the age of the blossoms as a factor in nectar production; yet several studies indicate that age is important. That flower age influences nectar secretion was first recognized in Europe more than a century ago by Bravis in 1842 and Bonnier in 1878 (Beutler 1953). However, in the early work the effect of pollination was not clear. Ewert (1936) reported that aged flowers in several lime species yielded twice the weight of nectar of young flowers (both protected from insect pollination). Beutler (1953) bagged horsechestnut (Aesculus hippocastanum) and was able to extract uniform amounts of nectar for a period of six days before a sharp decline of nectar occurred. Collison (1973) sampled Cucumis sativa blossoms and found that nectar was only secreted on the first day of anthesis with none on the days thereafter.

To gain more insight into this question in a North American species, bagged flowers of Asclepias syriaca were

Offprint requests to: A.K. Southwick, State University of New York, College at Brockport, NY 14420, USA studied for age effect on nectar production. Asclepias syriaca was chosen for this study because it produces copious amounts of nectar (Southwick et al. 1981), is in reasonable abundance in northern habitats, and flowers at a time convenient for study. It is also an important nectar producer for honey bees (Pellett 1976).

\section{Methods}

Two clones of $A$. syriaca were chosen at the University of Michigan Biological Station near Pellston, Michigan, USA (Cheboygan County, $45^{\circ} 33^{\prime} \mathrm{N}^{\prime} 84^{\circ} 41^{\prime} \mathrm{W}$ ). Site 1 was a disturbed area adjacent to the south facing wall of a building, about $20 \mathrm{~m}$ from the Douglas Lake shoreline. This area was about $2.3 \times 2 \mathrm{~m}$ in size and contained 30 stems, 8 with blossoms and 22 without blossoms. The flowers first opened here on 20 June and flowering peak was reached about 30 June 1981. Site 2 was located $300 \mathrm{~m}$ west of site 1 , on the north-facing lakeshore, and was $18 \times 13 \mathrm{~m}$ in size. Of the 443 stems counted in this clone, 66 were found with blossoms, and 377 without blossoms. Flowering in this area started on 30 June and peaked on 5 July 1981. Microclimate data (solar radiation, soil, stem and leaf temperatures, shaded air temperature, and relative humidity) were taken at both sites.

Plants were bagged with fine nylon mesh (28 openings per $\mathrm{cm}$ ) to exclude pollinators or nectar thieves. Only flowers in which anthesis was observed (full reflexing of petals) within a known four-hour period were chosen for the experiment. At site 1, 15 blossoms met this criterion ( 7 blossoms opened on 30 June and 8 on 1 July). At site 2 we monitored 21 blossoms (8 blossoms opened on 2 July and 13 on 3 July). Each blossom was labelled with a tag on the peduncle to assure repetitive sampling of the same individuals throughout the experiment.

Nectar samples were taken once each $24 \mathrm{~h}$ at both sites at 0700 (site 1) and 0800 (site 2) for seven days. Samples were collected in the early morning because the results of a preliminary sampling schedule indicated that main nectar production took place between 2400 and 0600 .

The nectar was withdrawn with calibrated $5 \mu$ micropipettes (Van-Lab, VWR Scientific). An aspirator tube was used to assure complete removal of all available nectar including nectar which could not be removed by capillary action alone. Nectar volumes were determined by measuring the length of nectar columns in the capillary tubes to the nearest $0.5 \mathrm{~mm}$ or $0.045 \mu \mathrm{l}$. 
Sugar content was analyzed immediately after sampling by using a light refractometer (American Optical, model 10431). Following our procedure previously described (Southwick et al. 1981), we converted nectar sugar concentrations as read on the refractometer (weight \%) to $\mathrm{mg}$ sugar per $100 \mu \mathrm{l}$ solution, and calculated mg sugar contained by the samples.

\section{Results}

Sugar production in bagged blossoms peaked about $50 \mathrm{~h}$ after the blossoms opened and declined to zero after about $120 \mathrm{~h}$ (Fig. 1). Nectar volume followed a similar schedule,

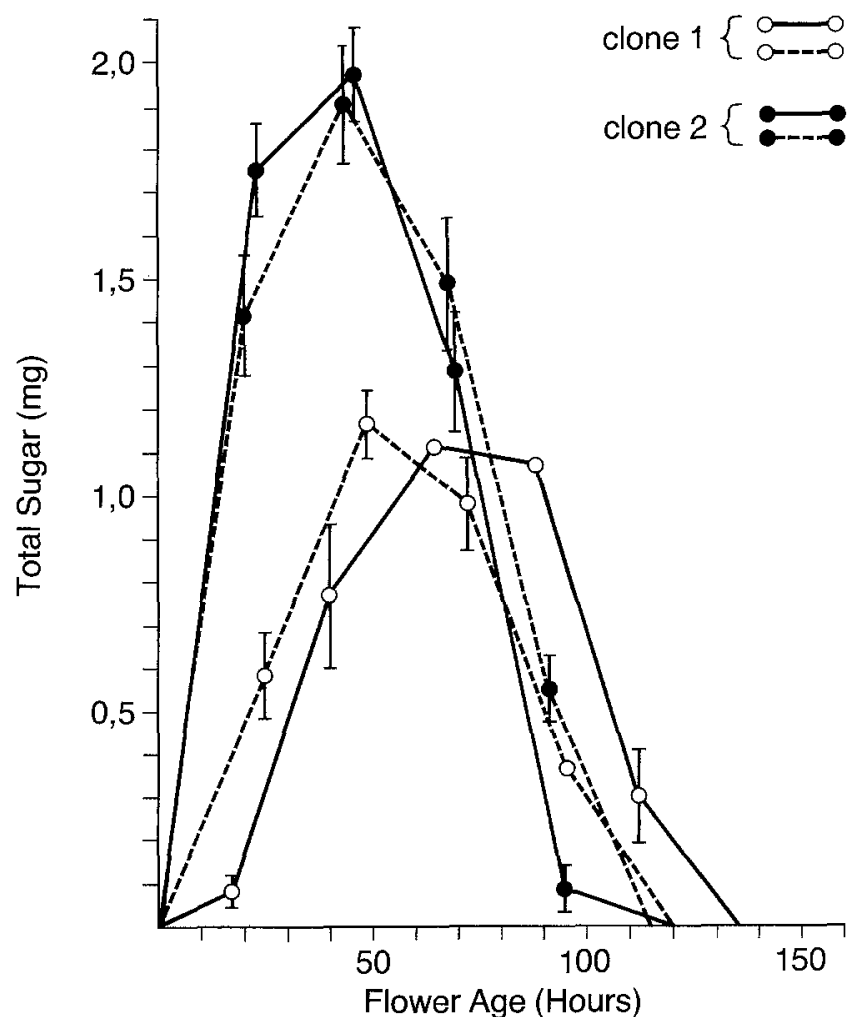

Fig. 1. Age dependency of sugar production in nectar samples taken from two clones of $A$. syriaca (bagged). Clone 1 was the drier site (lower curves) while nectar concentration generally decreased in the successive 24 h samples (Figs. 2, 3).

Several other patterns are clear from the Figures. The two sites were quantitatively different in their nectar volume and sugar yields. The plants from the drier site 1 showed a slight phase shift in production, peaking about 2-19 h later (sugar and volume) than the plants on site 2 . Nectar

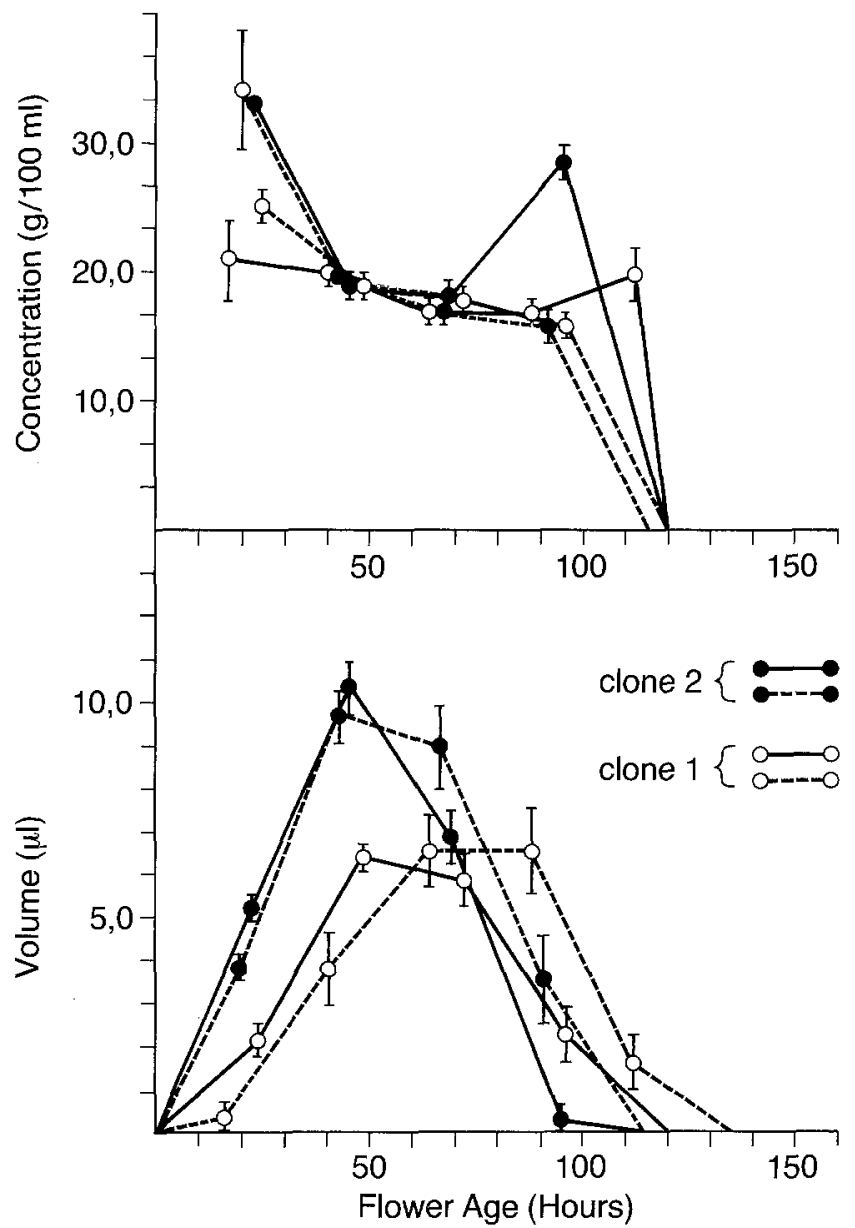

Fig. 2. Effect of flower age on nectar sugar concentration in $A$. syriaca (upper)

Fig. 3. Age effect on nectar volume production in $A$. syriaca (lower)

Table 1. Nectar Production in Bagged Asclepias syriaca ${ }^{\text {a }}$

\begin{tabular}{lllllll}
\hline & \multicolumn{2}{l}{ Highest 24-h Production $^{\mathrm{b}}$} & & \multicolumn{2}{l}{ 5-day Total Production } \\
\cline { 2 - 3 } & $\begin{array}{l}\text { Volume } \\
(\mu \mathrm{l})\end{array}$ & $\begin{array}{l}\text { Concentration } \\
(\mathrm{g} / 100 \mathrm{ml})\end{array}$ & $\begin{array}{l}\text { Sugar } \\
(\mathrm{mg})\end{array}$ & & $\begin{array}{l}\text { Volume } \\
(\mu 1)\end{array}$ & $\begin{array}{l}\text { Sugar } \\
(\mathrm{mg})\end{array}$ \\
\hline $\begin{array}{l}\text { Clone 1 } \\
(n=15)\end{array}$ & $6.6 \pm 0.11$ & $23.0 \pm 1.79$ & $1.2 \pm 0.03$ & & $17.7 \pm 1.30$ & $3.2 \pm 0.24$ \\
$\begin{array}{l}\text { Clone 2 } \\
(n=21)\end{array}$ & $10.1 \pm 0.36$ & $33.5 \pm 0.53$ & $2.0 \pm 0.03$ & & $24.4 \pm 0.92$ & $5.3 \pm 0.23$ \\
\hline
\end{tabular}

a Data shown as mean \pm S.E. Clone 1 sampled every $24 \mathrm{~h}$ between 1 July and 6 July 1981 . Clone 2 sampled every 24 h between 3 July and 8 July 1981

b Highest concentrations were not found on the same days as highest volumes and sugar contents

c Concentration values are refractometer readings $(\mathrm{g} / 100 \mathrm{~g})$ converted to $\mathrm{g} / 100 \mathrm{ml}$. Use of unconverted refractometer readings will result in errors in sugar production as high as $43 \%$ 
production peaked at 43 to $45 \mathrm{~h}$ after anthesis at site 2 and 48 to $64 \mathrm{~h}$ at site 1 . Even more apparent are the smaller $24 \mathrm{~h}$ and total life production volumes, and the $24 \mathrm{~h}$ and total life sugar values (Figs. 1 and 2, Table 1). Samples from single blossoms at site 2 averaged 1.5 times greater volume than those from site 1 . Peak volumes $(24 \mathrm{~h})$ from site 2 averaged $10.1 \mu \mathrm{l}$, while those from site 1 averaged $6.6 \mu \mathrm{l}$. Total volumes produced during the 5-day life of the flowers amounted to $24.4 \mu \mathrm{l}$ at site 2 and $17.7 \mu \mathrm{l}$ at site 1 . Daily sugar production peaked at $2.0 \mathrm{mg}$ per blossom at site 2 and $1.2 \mathrm{mg}$ at site 1 . Total sugar production by single blossoms averaged $5.3 \mathrm{mg}$ on site 2 and only $3.2 \mathrm{mg}$ at site 1 , about $40 \%$ less. All the values from site 2 were significantly greater than those from site $1(P<0.001$; see Table 1).

Nectar concentration was greatest in the first samples taken at both sites (Fig. 3) and amounted to $23.0 \pm 1.79 \mathrm{~g}$ sucrose $/ 100 \mathrm{ml}$ solution at site 1 and $33.5 \pm 0.53 \mathrm{~g} / 100 \mathrm{ml}$ at site 2 . From 43 to about $90 \mathrm{hrs}$ after flower opening the concentration at both locations remained at $17-20 \mathrm{~g} /$ $100 \mathrm{ml}$. However after $90 \mathrm{~h}$, half of the flowers showed increases again in concentration from 18.4 to $28.5 \mathrm{~g} / 100 \mathrm{ml}$ for site 2 and from 16.6 to $20.3 \mathrm{~g} / 100 \mathrm{ml}$ for site 1 .

Samples taken at any one time showed greater variation in volume than in concentration. This held true at most sampling times at either site. The coefficient of variation (CV) for volume data was $108 \%$, and only $20 \%$ for concentration data.

\section{Discussion}

We found a pattern of nectar production associated with flower age in two clones of Asclepias syriaca. The peak nectar volume occurring on the second day following anthesis is similar to the age-dependent effect found in other species in north temperate habitats. In several fruit tree species in northern Europe maximum sugar production was reported on the second day following anthesis (Beutler and Schöntag 1940). However, peak production varied from 1 to 3 days after anthesis among various Malus and Rubus varieties. Feinsinger (1978) also found that older pistillate flowers secreted less nectar than young staminate flowers in 5 tropical flowers visited by hummingbirds.

The substantial differences in volume and sugar production that we found between the two clones did not affect the age pattern. Several edaphic and microclimatic factors probably brought about these differences. For example, from earlier sampling in an area near clone 1, we noticed the cooler weather prolonged flowering and lengthened production time of nectar. Our sampling at clone 1 commenced on 1 July and the flowers were likely still under the influence of the previous cool temperatures. Sampling at clone 2 started after 2 more days of hot weather (3 July). Microclimatic conditions throughout the sampling time in both clones were hot and dry $\left(\bar{T}_{\max }=28.0^{\circ} \mathrm{C}, \bar{T}_{\min }=15.8^{\circ} \mathrm{C}\right)$. Each day was sunny with solar radiation levels always exceeding photosynthetic saturation levels (Southwick, unpublished data). Additional factors of the microclimate affecting nectar production differences between sites resulted from the location of clone 1 adjacent to a south facing vertical wall where soil moisture was low and the plants may have been water stressed. Shuel and Shivas (1953) found reduced nectar yields in snapdragons (Antirrhinum) when subjected to dry soil conditions, and Huber (1956) showed a direct effect of soil moisture on nectar secretion in several North European species.

At both sites the higher nectar concentrations at the start of the sampling period generally decreased with advancing age. The sudden increase in concentration at about $100 \mathrm{~h}$ may have been related to the effect of evaporation on the tiny volumes obtained $(0.3$ to $1.7 \mu 1)$. We found that evaporation was more rapid from a small droplet or thin film of nectar than a larger globule (unpublished data). Loper et al. (1976) found no significant change in sugar concentration of 3 citrus species as flowers aged. However, Huber's (1956) data show older European flowers (species not given) secreting nectar of lower concentration than younger blossoms.

If the plants in a clone function as one physiological unit, then a greater photosynthetic product would be expected from a greater number of total ramets (and more leaf photosynthetic area) represented in a clone relative to flowering ramets. The proportion of flowering ramets was $26.7 \%$ in clone 1 and $14.9 \%$ in clone 2 . We also found evidence of translocation between members within a clone (Southwick, unpublished data).

Genetic differences between these two clones were not documented, but could have contributed to the clonal difference in nectar production. A small difference in size of the cuculli between plants at the two sites was observed (qualitatively). The staminal hoods were larger and it was easier to insert the micropipettes at site 2. A larger flower would have more nectar tissue which would produce larger volumes of nectar.

Great care was taken during the sampling regime so as not to injure the flowers in any way. However, even in flowers that had never been subjected to any sampling before, large differences in cuculli nectar levels were noticed. Whether this is just due to a blockage in the capillary network or an adaptation to attract pollinators is not known. The cuculli are merely nectar holders, receiving the nectar from the stigmatic chambers which Galil and Zeroni (1965) found to be the only nectaria in the Asclepias flower. The nectar moves from the stigmatic chamber through an extensive capillary system into the cuculli. A few flowers which had all nectar removed with the micropipettes were examined under the microscope and the entire stigmatic area still glistened with nectar. We doubt that this had any effect on our measurements of volume. Unbagged flowers, appearing devoid of nectar during the daytime often were observed crowded with ants and dipterans which apparently lick nectar directly from the stigmatic chamber, even though the cucilli are empty (Galil and Zeroni 1965).

Flowers do not open synchronously in a single umbel of $A$. syriaca or most other species with umbel or raceme morphology. Therefore, because of the age effect on nectar production which produced nectar peaks regularly about $50 \mathrm{~h}$ after anthesis, the nectarivores would find a number of blossoms with high nectar volumes throughout the flowering cycle of the plant. These high volumes would reward the pollinator's search and encourage other visits.

Our highest mean total volumes for individual flowers at site 1 and site 2 were 17.7 and $24.4 \mu$ respectively. Even with a large range in nectar volume and total sugar among the individual flowers, only the highest volume and sugar values from site $1(30.5 \mu \mathrm{l}$ and $5.3 \mathrm{mg})$ fell outside two standard deviations. Willson and Bertin (1979) recorded total nectar volumes of repeat-sampled flowers of $A$. syriaca in 

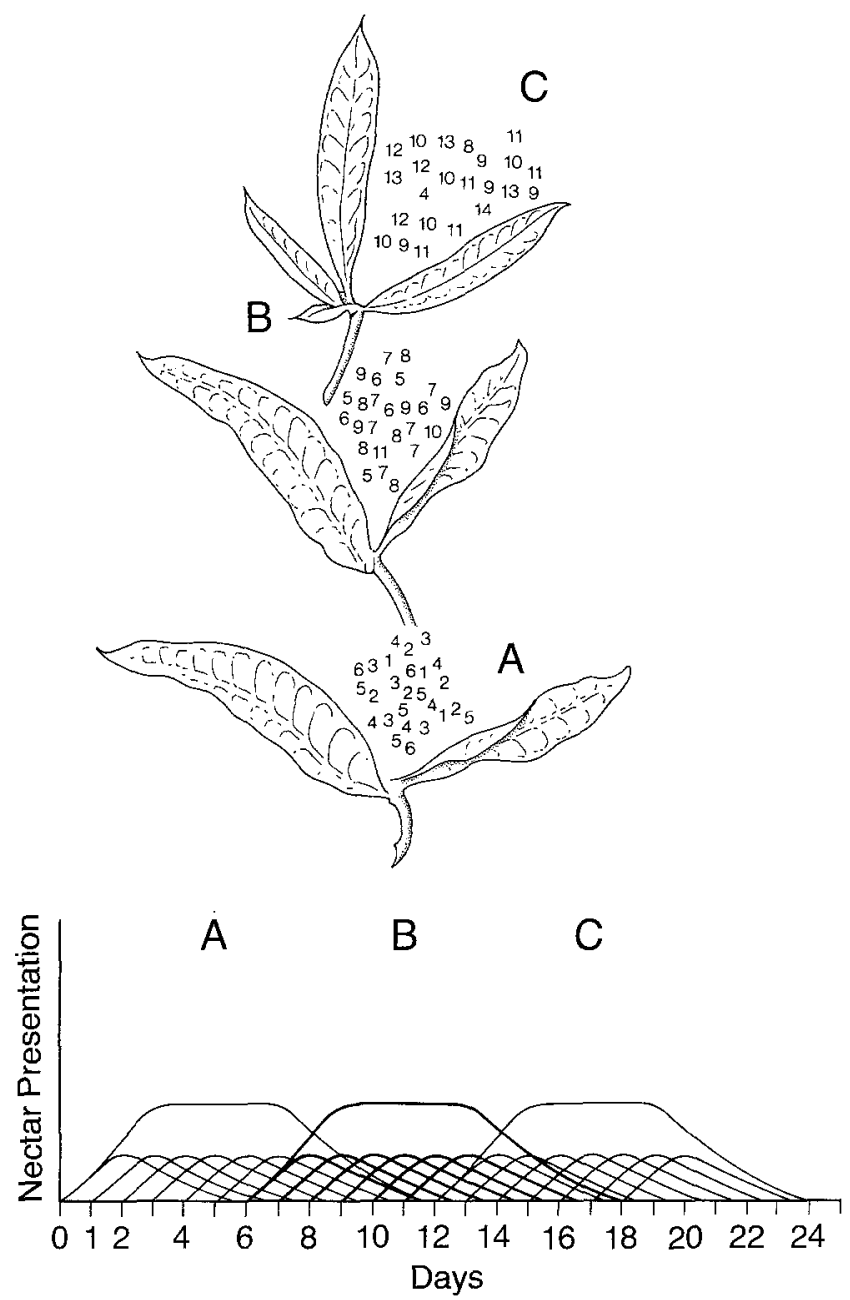

Fig. 4. a Pattern of blossoming and nectar presentation in a single stem of A. syriaca. Each number represents the day of blossom opening (upper). b Pattern of overall nectar production in a ramet of $A$. syriaca (lower). See text for explanation

southern Illinois to average $39.7 \mu$ l. Their higher value could be due to genetic differences between populations, environmental stresses of the habitat, or latitudinal climatic differences. More investigation needs to be done to clarify these roles.

Originally we had expected to encounter several blossoms with high nectar volumes when sampling large numbers of flowers. When sampling many flowers of Lonicera maackii, we encountered a few single flowers containing high nectar volumes and labelled these "lucky hits" (Southwick 1982; Southwick et al. 1981). We believed this "lucky hit" production was actually an energy-conserving method developed by the plant. Variable amounts of nectar volume would result in more searching and scrabbling by insect visitors than constant volumes, thus the plant would benefit by producing unequal amounts in the flowers. Further study of nectar presentation of total inflorescences in A. syriaca and other species might shed more light on this "lucky hit" theory. However, with anthesis taking place over a few days, the resulting sequential pattern of flower blossoming and nectar presentation virtually assures a good supply of nectar reward at a single plant stem for several days. The sure reward in the clone would extend over many days to two weeks or more. As Fig. 4a illustrates, individual blossoms open first in the lowest umbel, then the next higher, continuing to the top-most umbel. Nectar presentation patterns, then, would resemble the sketch in Fig. 4b, where each of the small curves represents nectar production by a single blossom. The three larger curves show the summed nectar production for each of three umbels.

The rate of anthesis and nectar production are influenced by genetics, climatic and edaphic conditions, yet we found the pattern to always be the same. Thus nectarivores always find some flowers at their peak production and some new or old blossoms at the same time. This is rewarding to the insect, and energy-conserving for the plant. Such an age pattern of nectar presentation therefore provides for better foraging and increased pollination.

Acknowledgements. We thank Claudia Jolls (University of Michigan) and Steve Weller (University of Chicago) for enlightening discussion and comments on the manuscript. We also thank David M. Gates (University of Michigan), Boyd R. Strain (Duke University) and an unknown reviewer for reading the manuscript. Field sites and laboratory space were provided by The University of Michigan Biological Station at Douglas Lake. This work was supported by the Andrew W. Mellon Foundation and funds from The Research Foundation of The State University of New York.

\section{References}

Beutler R (1953) Nectar. Bee World 34: 106-116, 123-136, 156-162 Beutler R, Schöntag A (1940) Über die Nektarabscheidung einiger Nutzpflanzen. Z. vergl. Physiol. 28:254-285

Browne CA, Zerban FW (1941) Physical and chemical methods of sugar analysis. 3rd ed. John Wiley and Sons Inc. New York

Collison C (1973) Nectar secretion and how it affects the activity of honey bees in the pollination of hybrid picling cucumbers, Cucumis sativa L., M.S. thesis, Michigan State Univ East Lansing

Corbet SA, Willmer PG, Beament JWL, Unwin DM, Prŷs-Jones OE (1979) Post-secretory determinants of sugar concentration in nectar. Plant Cell Envir 2:293-308

Ewert R (1936) Honigen and Samenansatz des Rotklees 1936. Deutsch Imkerführer 10:476-480

Faegri K, van der Pijl L (1979) The principles of pollination ecology. 3rd ed. Pergamon Press NY

Free JB (1970) Insect pollination of crops. Academic Press, London

Galil J, Zeroni M (1965) Nectar system of Asclepias curassavica. Botan Gaz 126:144-148

Huber H (1956) Die Abhängigkeit der Nektarsekretion von Temperatur, Luft- und Bodenfeuchtigkeit. Planta 48:47-98

Jaycox ER (1976) Beekeeping in the mid-west. Univ Illinois College Agri Coop Ext Serv Circ 1125

Johnson LH (1946) Nectar secretion in clover. Effect of soil and climate on honey production. New Zealand Agri 73:111-112

Loper GM, Waller GD, Berdel RL (1976) Effect of flower age on sucrose content in nectar of Citrus. Hort Sci 11:416-417

Meuse BJD (1961) The story of pollination. Ronald Press Co NY

Oertel E (1944) Variation in the sugar concentration of some southern nectars. J Econ Ent 3:525-527

Park PW (1929) The influence of humidity upon sugar concentration in the nectar of various plants. J Econ Ent 22:534-544

Pellett FC (1976) American honey plants. Dadant and Sons, Hamilton, Illinois

Percival M (1965) Floral biology. Pergamon Press NY

Raw GR (1953) The effect on nectar secretion of removing nectar from flowers. Bee World 34:32-35 
Robinson IA, Oertel E (1975) Sources of nectar and pollen. In: Dadant and Sons (eds) The hive and the honey bee, Dadant and Sons, Hamilton, Illinois p 283-302

Shuel RW (1975) The production of nectar. In: Dadant and Sons (eds) The hive and the honey bee, Dadant and Sons, Hamilton, Illinois $\mathrm{p} 265-282$

Shuel RW, Shivas JA (1953) The influence of soil physical condition during the flowering period on nectar production in snapdragon. Plant Physiol 28:645 651

Southwick EE (1982) "Lucky Hit" nectar rewards and energetics of plant and pollinators. Comp Physiol Ecol 7:49-53

Southwick EE, Loper GM, Sadwick SE (1981) Nectar production, composition, energetics and pollinator attractiveness in spring flowers of western New York. Amer J Bot 68:994-1002
Southwick EE, Southwick AK (1980) Energetics of feeding on tree sap by ruby-throated hummingbirds in Michigan. Amer Midland Nat 104:328-333

Stephenson AG, Thomas WW (1977) Diurnal and noctural pollination of Catalpa speciosa (Bignoiaceae). Syst Bot 2:191-198

Willson ME, Bertin RI (1979) Flower-visitors, nectar production and inflorescence size of Asclepias syriaca. Can $\mathrm{J}$ Bot 57:1380-1388

Wykes GR (1953) The sugar content of nectars. Biochem J 53:294-296

Received August 5, 1982 